\title{
COL4A3 wt Allele
}

National Cancer Institute

\section{Source}

National Cancer Institute. COL4A3 wt Allele. NCI Thesaurus. Code C52481.

Human COL4A3 wild-type allele is located within 2q36.3 and is approximately $150 \mathrm{~kb}$ in length. This allele, which encodes collagen alpha-3 (IV) chain protein, is involved in the maintenance of the structure of the basement membrane. Mutation of the gene is linked to an autosomal recessive form of Alport syndrome. 